\title{
Impact of Scrum Adoption on Enterprise in Transition for Software Development
}

\author{
B. Reddaiah, K. Srinivasa Rao
}

\begin{abstract}
In every product development companies should be aware about the quality and customer's satisfaction of the product that they are developing. To get high quality product based on the customer and circumstances of development, suitable process model has to be used in development. Scrum framework is the one which focus on maximize flexibility and minimize transparency in project development. Most of the companies are going with Scrum as it is simple to use and it is a tool rather than process model. When new process models are chosen, they need to be adopted into the enterprise and has to go for a change. As adoption is a continuous process, at least for some period the behavior and new culture of the new framework has to be managed in its early days. When new concept is introduced there should be smooth transition from exiting to new ones. In this work impact of Scrum adoption in developing value-added card products and in financial services is discussed.
\end{abstract}

Keywords: Process models, Project development, Scrum, Adoption, Transition, Value added card products, Financial Services

\section{INTRODUCTION}

$\mathrm{S}_{\text {crum is part of agile group with agility, iterative and }}$ incremental nature (Reddaiah and Srinivasa Rao, 2017; Reddaiah et al., 2016). Agile group of methods are good at developing business applications and in this group Scrum (Schwaber, 1995) and extreme programming (Beck, 1999) are widely used. Friendly nature is the foremost factor for the acceptance of agile methodologies (Cockbum and Highsmith, 2000; McManus, 2003; Schatz and Abdelshafi, 2005). Exactly discussing about Scrum it is not merely a process model like waterfall model and others, but it is a tool and a framework that resembles process model and can handle big problems and gives highest possible results. It delivers the software products in less time and in a better and cooler way (Schwaber, 2004; Schwaber, 2002). This framework allows us to make use of different processes and techniques.

Companies started using Scrum from early 1990s as it is good in managing complex problems. It is a light weighted process and easy to use. Because of this nature, companies started

Revised Manuscript Received on December 30, 2019.

* Correspondence Author

Reddaiah Buduri*, Department of Computer Applications, Yogi Vemana University, Kadapa, Andhra Pradesh, India. E-mail: b.reddaiah@yogivemanauniversity .c.in

Srinivasa Rao K., Department of Computer Applications, Yogi Vemana University, Kadapa, Andhra Pradesh, India. E-mail: kanususrinivas@gmail.com

(C) The Authors. Published by Blue Eyes Intelligence Engineering and Sciences Publication (BEIESP). This is an open access article under the CC BY-NC-ND license (http://creativecommons.org/licenses/by-nc-nd/4.0/) believing that it is worthy and relatively good in software project development. This framework also helps in developing new practices that the company can improve. As other traditional process models, Scrum framework has its own teams, related roles for team members, procedures, artifacts and rules. Set of rules that exist in Scrum helps in unifying the events, roles, and artifacts that govern the relationship and interaction among the Scrum team. All the elements in this framework are intended and used for definite purpose. This is the basic reason for the success of Scrum largely in industry.

\section{A. Scrum Theory}

The framework of Scrum is a control hypothesis that is based on practical procedure and the framework is shown in the Figure 1. This emphasizes that experience gives more knowledge to team members and decision making is based on the knowledge. The approach of Scrum towards project development is iterative and incremental that increases certainty and manages risks effectively in products. This is made possible in Scrum by its transparency, inspection, and adaptation.

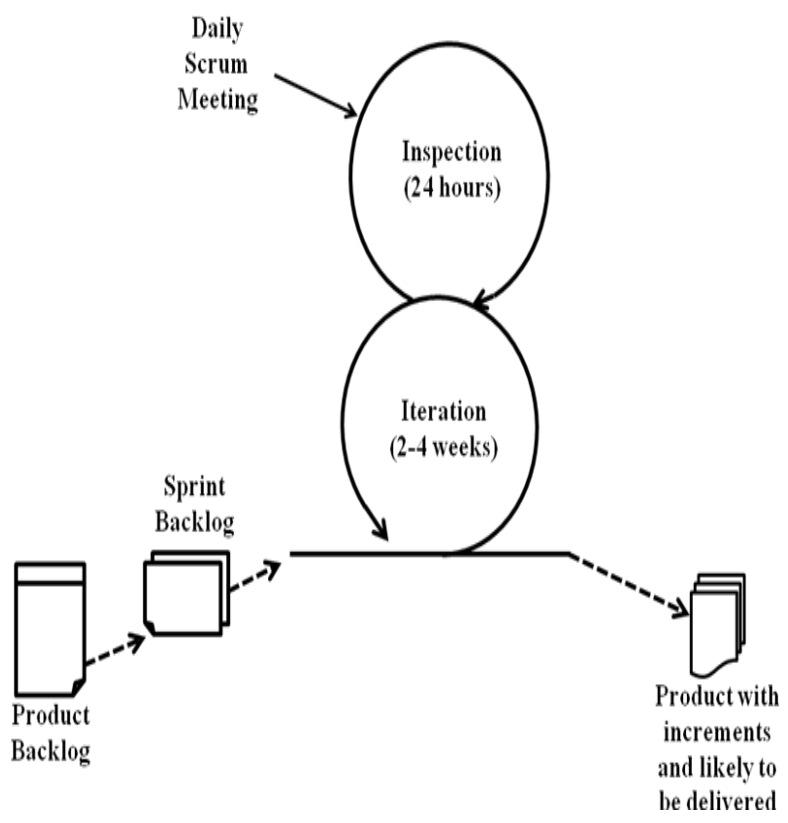

Fig. 1 Scrum Framework

\section{1) Transparency}

The most important feature of any process model is to be visible in nature for all that is accountable for the outcome. Transparency is the one that is based on common standards, so that people can come to a similar conclusion once they share what is seen. For instance, a general form that refers to process should be shared by all the team members. 
Likewise, the people those are executing the job and people taking work should have general form.

\section{2) Inspection}

The main advantage of Scrum is that it allows users to regularly examine artifacts and state of development headed to sprint goal for identifying unwanted variances. These kinds of inspections that are allowed by Scrum are more favorable if they are executed by skilled people. But every care should be taken so that these inspections should not disturb the actual work.

\section{3) Adaptation}

In inspection if any deviation is identified that goes beyond acceptable limits that may result in products acceptance and has to be adjusted. Proper adjustment has to be carried-out to minimize further deviation.

\section{ADOPTING SCRUM}

Software product development needs to achieve high quality products and standards. To get these things done development process has to be altered according to the changing environment. In achieving high quality new bunch of methodologies called agile group sits in forefront. Among these methodologies Scrum framework is widely accepted and used. If an enterprise chooses to bring Scrum into its development, first it has to be adopted. This is a process that the enterprise that has expertise in using old methods has to shift from their strong holds to new one.

In case of Scrum, once the enterprise decides to go for adopting, Scrum needs a new enterprise culture (Liker, 2004). All the old practices have to be put aside and new practices of Scrum have to be learnt and implemented. This is not that much easy for an enterprise and its people to do and to go for a change immediately. So adoption should be done as continuous process for some period of time and at least it is up to the time that people become expertise in using the framework. For this to happen, people adopting Scrum have to put huge effort in changing their culture and practices that they are previously good at. The Figure 2 shows the process of adoption and implementing the projects by the enterprise [Liker, 2004; Reddaiah et al., 2016).

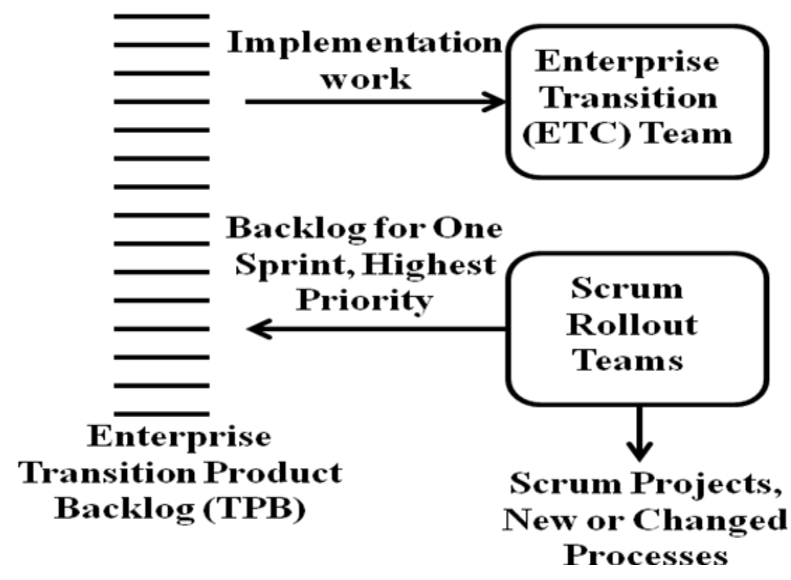

Fig 2: Scrum adoption process diagram in Implementation of Project

\section{SCRUM IN ITS EARLY DAYS}

Once the adoption is completed effective results may not be possible immediately. It takes time to show results as the enterprise and its people are not changing immediately. At the end of the first month of Scrum in the enterprise the adoption process may be completed and the first rollout sprints throughout the enterprise will be in progress (Poppendieck, 2005). Figure 3 shows the first rollouts at the end of first sprints and probably at the end of first month.

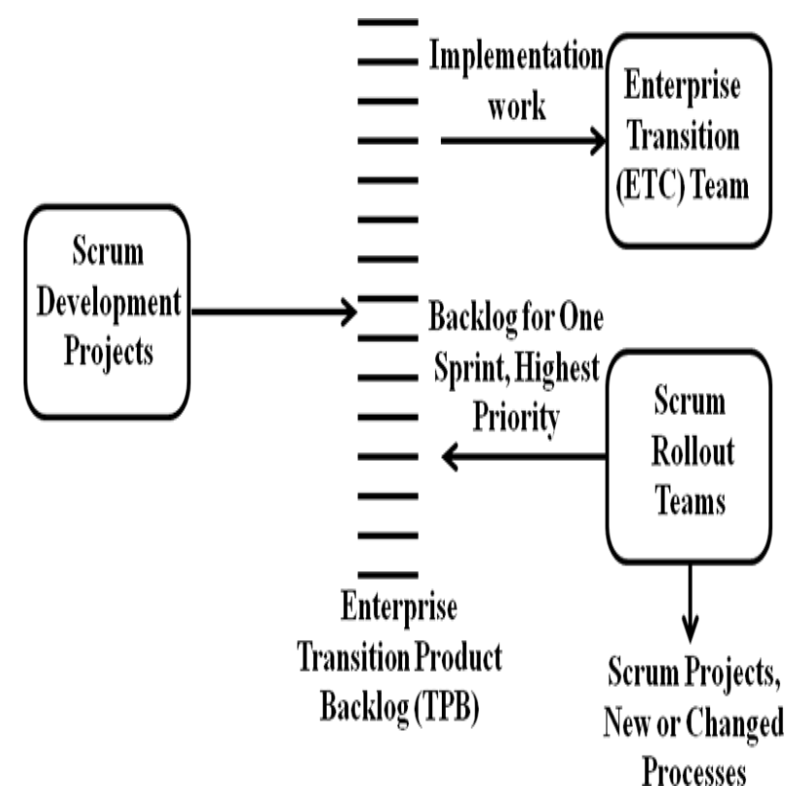

Fig 3: Scrum Rollout

When it comes to second month the enterprise might have started many projects by using Scrum framework and with this the enterprise involved in gathering the required recourse for all the projects that have started. By the end of second month and at the start of third month the team starts assessing the obstacles and starts handling the obstacles.

\section{RIGIDNESS IN APPLYING SCRUM}

When traditional process models are used in project development, they may exhibit some non functional events and these are easily made visible once Scrum is used. Problems that rise by non functional events are blown up through Scrum. As Scrum by nature is incremental and iterative, at the time of adoption by any enterprise adjustments are to be monthly but not at the end of it. So, because of the nature sub products at the end of the each and every month are delivered which can be executed, thus helpful to the customer. When executable sub products are delivered to customers along with benefits to them, if any problem arises, they can be shown to the Scrum team for proper action. In addition to that skilled people of the industry may feel uncomfortable with newly adopted methods (Reddaiah and Srinivasa Rao, 2017). When the above said problems are effectively handled by them, they can understand the difference between Scrum and other traditional models used for development.

Published By:

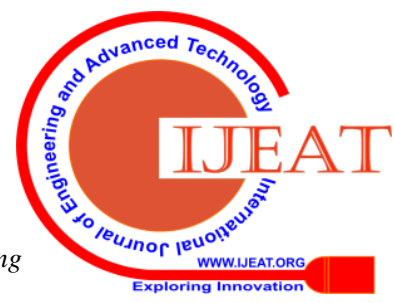




\section{TATA GROUP IN TRANSITION}

As discussed in chapter 4 it is more beneficial and enterprise that finds it may move forward. In this chapter transition impact on Tata Group Company that moved to Meta Scrum is discussed. It is felt that this company that made the move is more courageous which may be motivated by requirements and insight. If these motivated parameters don't occur in this group probably, they may never enthusiastically initiate to use Scrum. Enterprises that are forced to change will choose an easy way by hiring management consultants, this step may be to protect themselves from reorganizing themselves which is a difficult one, but not in the case of Tata group.

Enterprise that uses Scrum finds the difference. Traditional models are base on theoretical impulses, whereas Scrum is truly based on failures and dysfunctions. The difference is due to difference in people, problems and importance of the problem. The common aspect is Scrum is to be considered as a tool for change. In this work Tata group identified the values of the framework primarily and then pushed into Scrum adoption.

\section{A. TATA Group}

Tata Group is an enterprise that builds value added card products like gift cards for various amounts. Customers for this enterprise are from banking sector, various insurance companies and also retailers. This Tata enterprise has complicated central structure. Its main characteristic is based on value added card template where customers are allowed to describe explicit features. Developing unit at Tata Group modify and prepare a special template in a unique way and sell the cards to consumer of it. This capability of Tata Group in quickly developing classy products made this company and placed it in top position. Developing the card project by this company takes more than four to five months. Tata Group's business model is to at-least crack yet on these projects. When the complete product takes four to five months to get released, Tata group identified Scrum that is facilitating to release working sub products to customer intermediately. In this case customer generates profit in the form of transaction fees as soon as they start using value added cards.

\section{B. Circumstances}

Tata Group customers are not satisfied with the way the projects are build. This situation is due to late delivery or not delivering the customized value-added cards. The delay in product delivery is because the project developing team starts the process of development by considering the specifications that are in contract. But due to changes in specifications that is possible in software development delivery takes more time than specified in the contract.

To handle this situation, Tata group started working more on controlling the situation and to reduce the negative consequences. But damage that took place is showing its effect and started increasing in number. Because of this size of customers that are miserable in the group also enlarged. Due to this even though there is nearly 50 percent of staff turnover at Tata Group, only 10 to 20 percent of employees were delighted to work there.

Because of this even though there are more products that are required by customers for coming season group remained quiet. As the customer is not satisfied with existing product, they were persisted on putting severe penalties for late delivery. This is because due to late delivery the products are not going to be very much useful if the delivery is subsequent to the holidays. In the other side if one value card in the market gets success, the remaining customers desire to supply a card that has more complicated functionality than the previous. Due to this Tata Group enterprise got new contracts which are more than the capacity of it to execute, and the enterprise could not handle the situations that lead enterprise success to danger. Because of this competition for the Tata Group enterprise increases as it started struggling to meet the requirements of customer.

On the other side experienced and expert employees are not happy and start leaving the Tata group. Tata Group enterprise also couldn't get new people and if get people, training them quickly to meet the demand is not that much easy. In handling these issues Tata Group enterprise started identifying the possibilities like offshore project development to handle timely delivery of projects. Along with timely delivery, the idea of the enterprise is to train key employees in an offshore enterprise so that the remaining employees can be trained by them in the enterprise itself. The offshore enterprise would provide additional people until requirement is satisfied and is an ideal way to meet the demand for resources. But this solution didn't work because the offshore enterprises took more time. This showed its effect in synchronizing the changes to main functionality and more frustration and confusion was developed.

\section{Application of Meta Scrum}

Tata Group enterprise was in a forced situation that they were prepared to attempt any new idea as they felt that this is the worst situation for them and it could not be worse than this situation. After a serious taught and discussion by management at Tata Group they stated thing about Scrum and they were confident that it would help the enterprise to come out the bad situation. Fortunately, Tata Group has a good process improvement group which is a top-down, command and control, metrics-driven one. Earlier to this situation also they executed a value chain learning process with which they can identify useless practices, based on change in customer requested process.

As an inevitable move Tata Group adopted Scrum in the enterprise. In short span of time the process improvement group took the initiative and changed all the on-hand projects to Scrum. Once change has been made the enterprise constructed new Scrum teams, identified Scrum masters and identified product owners. As a whole 20 Scrum teams, 20 new Scrum masters and 20 new product owners were formed. After the formation of teams, metrics has been implemented to examine the workflow in Scrum projects. Daily meetings were held to evaluate impediments, advancements and drifts in the metrics. As the process started by using Scrum, problems were transparent and fixes were quickly planed and organized. With this enterprise started experiencing the increase in productivity twice than previous development. 
This happens within the first three months after adopting Scrum.

After adopting Scrum Tata group started building Meta Scrum with new states and new tables to the existing Scrum are used. The structure of Meta Scrum used in Tata group is shown in the Figure 4 It uses several teams working on the same product. Daily Scrum appointed one member as representative, to take part in a daily meeting with the representatives of other teams. These representatives are the technical contributors with proper solutions for impediments. For planning and managing enterprise transition teams are properly constructed and employed along with Scrum rollout teams.

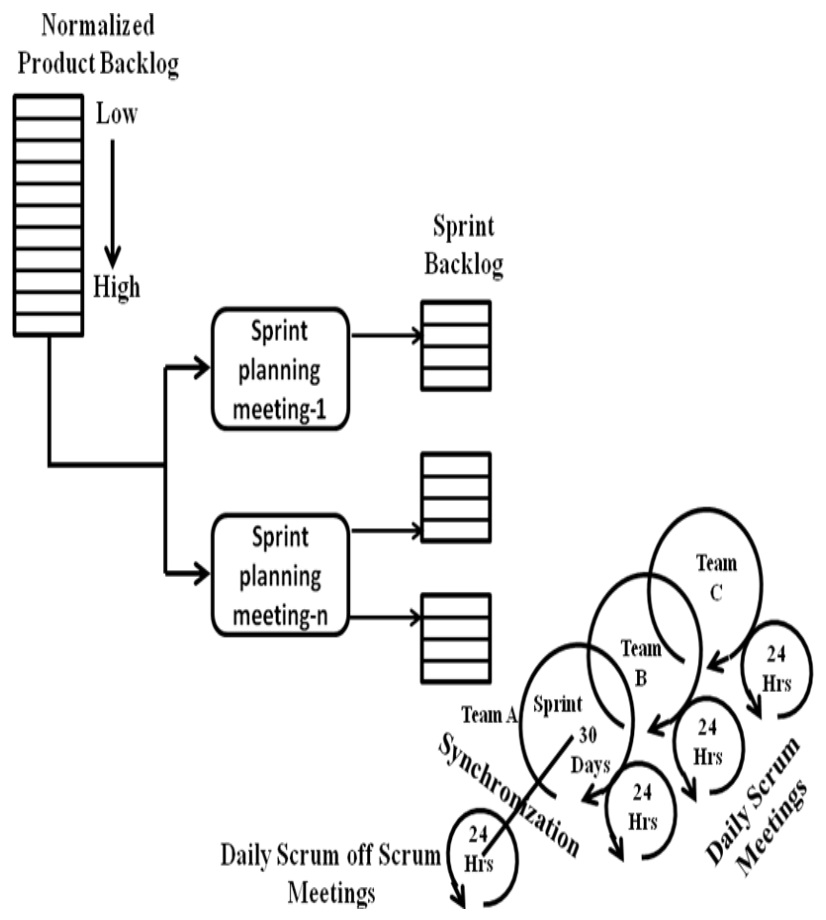

Fig 4: Overview of Meta Scrum used in Tata group

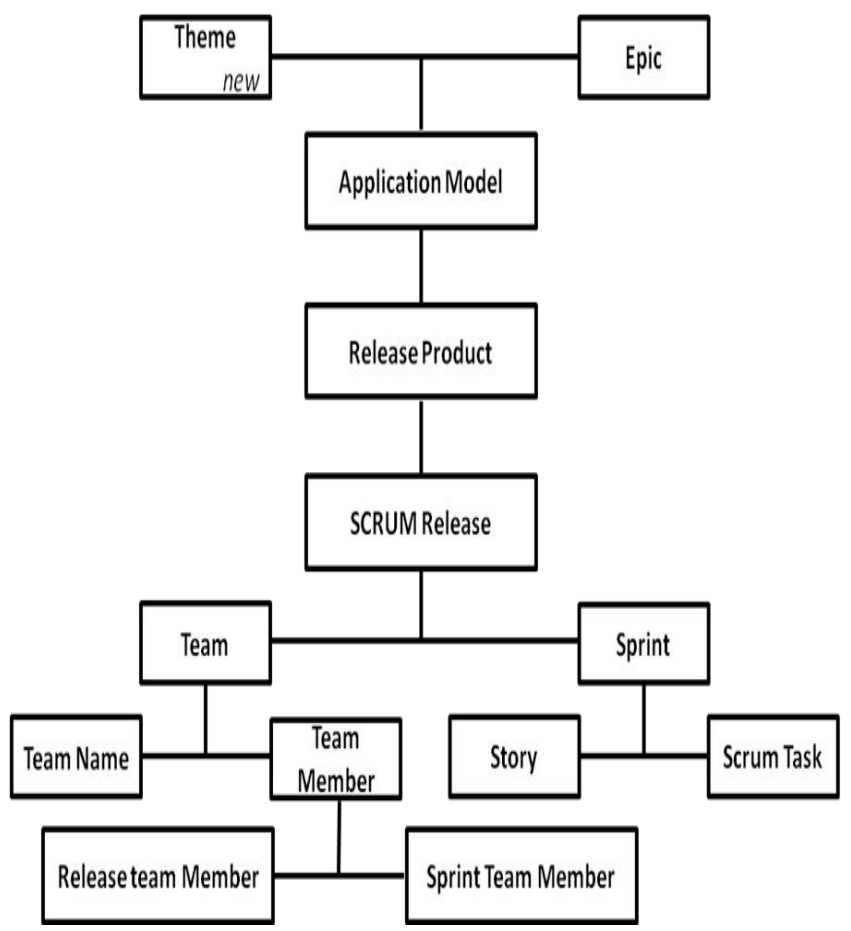

Fig 5: Overview of Meta Scrum used in Tata group
Figure 5 shows the software development life cycle Scrum process pack, plug-in adds several new tables to the existing SDLC Scrum tables. This is used as the reference by the Tata group and some new tables has been picked by management. The following is the list shown in Table 1 with changes to Scrum process pack in Scrum tables that have been adopted in Tata Group and introduced in state and release fields of developing value-added card products.

Table: 1 Scrum process pack with changes to SDLC-Scrum table

\begin{tabular}{|l|l|l|}
\hline $\begin{array}{c}\text { S. } \\
\text { No }\end{array}$ & Table & \multicolumn{1}{c|}{ Revised } \\
\hline 1 & Story & $\begin{array}{l}\text { Priority and state fields have been altered to } \\
\text { decide and fix the sprint and release. }\end{array}$ \\
\hline 2 & Sprint & $\begin{array}{l}\text { Status filed has been altered to determine } \\
\text { the release of a product. }\end{array}$ \\
\hline 3 & Release & $\begin{array}{l}\text { Status fields are with updated information } \\
\text { of release of product. }\end{array}$ \\
\hline
\end{tabular}

\section{Results}

The Results derived by TATA group are discussed in Table 2.

Table: 2. Improved areas in TATA group once Scrum is adopted

\begin{tabular}{|c|c|c|}
\hline $\begin{array}{c}\text { Company/ } \\
\text { Phase }\end{array}$ & $\begin{array}{c}\text { Improved } \\
\text { Areas }\end{array}$ & Description \\
\hline \multirow[b]{3}{*}{$\begin{array}{l}\text { TATA } \\
\text { Group }\end{array}$} & $\begin{array}{l}\text { Satisfaction of } \\
\text { Employees }\end{array}$ & $\begin{array}{l}\text { After two months evaluation has } \\
\text { been made on Scrum projects in } \\
\text { Tata Group enterprise. Over } 85 \\
\text { percent of employees are } \\
\text { delighted working with Scrum. }\end{array}$ \\
\hline & Project Time & $\begin{array}{l}\text { Most of the projects with Scrum } \\
\text { are being concluded on time } \\
\text { with all the requirements that are } \\
\text { desired by customer. }\end{array}$ \\
\hline & $\begin{array}{l}\text { Customer's } \\
\text { Approach }\end{array}$ & $\begin{array}{l}\text { In addition to that there is a } \\
\text { change seen in customer's } \\
\text { perspective in terms of price, } \\
\text { date, contracts. } \\
\text { Due to this customers sense } \\
\text { control in product development } \\
\text { and the risks involved in } \\
\text { development. Once the customer } \\
\text { trusts the ability of developer, } \\
\text { they hire the same team for the } \\
\text { next six months for developing } \\
\text { the envisioned projects. } \\
\text { Customer once gets the project } \\
\text { done then they think of same } \\
\text { team for the next project. } \\
\text { Sometimes few customers set } \\
\text { price and date of project and } \\
\text { Tata Group enterprise is set to } \\
\text { deliver the project in specified } \\
\text { time but, customer hedges its } \\
\text { bets, assuming that Tata group } \\
\text { would probably be late. }\end{array}$ \\
\hline
\end{tabular}




\section{HDFC IN TRANSITION}

In this chapter transition impact on Housing Development Finance Corporation (HDFC) that moved to Scrum is discussed.

\section{A. Housing Development Finance Cooperation (HDFC)}

Housing Development Finance Corporation (HDFC) is a private largest bank based financial services companies in India with Rs. 1,189,432 crores as approximate assets. This financial company affords retail and business banking, consumer funding, investment banking products and provide services to both individuals and companies.

\section{B. Circumstances, Phase 1}

HDFC Company has its own Information Technology (IT) sector with about 1,000 professionals for software development and with a budget around Rs. 10000 crores. The software development sector has problem consistency delivering system that concentrates on their internal customers only. Because of only dealing with internal customers, management of developing unit as a solution obtained and rolled out a new methodology called Really Improved Process (RIP). RIP rollout was planned and implemented by software developing unit for a period of two years. With all the effort after two years internal customers find no difference and are not happy as they find no difference and improvement.

Consequently, the management started meeting the project managers weekly to review the metrics of important projects. In spite of all these efforts project managers understand that a small mistake may result in career damage and could not function properly. Immediately the management changed their focus from RIP to Meta Scrum that is showing good success on different vital projects. This replacement started with acquiring Scrum masters along with changes to SDLC-Scrum table into the company. These Scrum master examined the situation and identified that users are not interested in IT rather they are comfortable in buying packages. They determined that Scrum was suitable at Humongous as Scrum's accountability and empowerment with creativity were more helpful for the company.

\section{Application of Meta Scrum, Phase 1}

The software development unit along with Scrum masters didn't straight away started choosing either roll out or Meta Scrum and used osmosis approach. They optionally selected Meta Scrum for projects where both the customers and the project team are interested. This resulted in visualizing the success of projects to others. With this the HDFC IT unit started giving training to management, project managers and customers who showed interested in Meta Scrum. The training is also given to Software Development Support Center where project are decided to develop using Meta Scrum.

Software Company started a transition to Meta Scrum and started eliminating exceptional problems or impediments that are listed and prioritized by management. This list that has impediments is called transition Product Backlog. The removal of impediments is started by commencing Sprints and the impediments identified are added to the product backlog. With this Scrum teams are created and these transition Scrum teams turn into a continuous process. These Scrum teams for a project are built and trained by software development support center based on preconditions that are set by company.

\section{Results}

The Results in phase 1, derived by HDFC bank are discussed in Table 3.

Table: 3.Improved areas in HDFC Corporation after adopting Scrum

\begin{tabular}{|l|l|l|}
\hline $\begin{array}{l}\text { Company/ } \\
\text { Phase }\end{array}$ & \multicolumn{1}{|c|}{$\begin{array}{c}\text { Improved } \\
\text { Areas }\end{array}$} & \multicolumn{1}{|c|}{ Description } \\
\hline Troject & $\begin{array}{l}\text { Within period of } 18 \text { months, quite a } \\
\text { few important projects were } \\
\text { successfully completed by applying } \\
\text { Meta Scrum. }\end{array}$ \\
\cline { 2 - 4 } & $\begin{array}{l}\text { Role of } \\
\text { Management in } \\
\text { using } \\
\text { Meta Scrum }\end{array}$ & $\begin{array}{l}\text { When the Software Development } \\
\text { Support Center started using Meta } \\
\text { Scrum the level of expertise of } \\
\text { developers in different teams of } \\
\text { Scrum was low. Most of the } \\
\text { customers are unaware of Meta } \\
\text { Scrum and they were still in a mood } \\
\text { of expressing their requirements to } \\
\text { developing teams rather than taking } \\
\text { responsibility in development. The } \\
\text { IT wing of HDFC also didn't bring } \\
\text { Meat Scrum fully, but instead they } \\
\text { were using vocabulary of Meta } \\
\text { Scrum with daily Scrum. }\end{array}$ \\
\hline HDFC & $\begin{array}{l}\text { Even though the management is } \\
\text { giving good support to IT wing by } \\
\text { Finance } \\
\text { Corporation/ } \\
\text { Phase 1 }\end{array}$ & $\begin{array}{l}\text { Scrum had not turn into regular } \\
\text { framework to develop software } \\
\text { projects within the company. } \\
\text { Majority of the employees in the IT } \\
\text { wing were still comfortable with } \\
\text { their old way of developing projects } \\
\text { as their muscle memory showed the } \\
\text { influence on the experts. The } \\
\text { experts saw the Meta Scrum as a } \\
\text { passing shower as other novel } \\
\text { approaches that are seen over the } \\
\text { years than traditional and modern } \\
\text { approaches. }\end{array}$ \\
\cline { 2 - 3 } & $\begin{array}{l}\text { Change in } \\
\text { Memaste }\end{array}$ & $\begin{array}{l}\text { On the other hand, when internal } \\
\text { and external customers have an } \\
\text { important project, they demanded to } \\
\text { go for Meta Scrum. With the } \\
\text { success of such projects they were } \\
\text { seen as benchmark in the user } \\
\text { community. }\end{array}$ \\
\hline
\end{tabular}

\section{E. Circumstances, Phase 2}

A set of customers of HDFC are satisfied with its Software Development Support Center. Positive nature in all levels in IT wing is seen among some developers. The production unit and users are satisfied with best possible solutions. At this point most of the people are aware of Meta Scrum and its vocabulary is extensively used. 
The management at this instant faced a problem of using the capital of goodwill to enlarge the beachhead.

\section{F. Application of Meta Scrum, Phase 2}

Management and the Scrum masters determined to move from osmosis inclusion of Meat Scrum to something new. The change is made from cosmetic change to genuine change in using Meta Scrum for projects. To make this possible the management and the Scrum masters gathered each and every one together and basic rules have been framed. With these guidelines in Software Development Support Center everybody is anticipated to use Meta Scrum fully. With this act all the results have been expected to improve.

The Software Development Support Center at this point focused on support, training, consulting and coaching to projects in the group. Projects that are developed by using Meta Scrum are subjected to Scrum audits to decide accurate use of Meta Scrum. Metrics are collected during daily Scrum and evaluated by Software Development Support Center. The most important metric would be surprises and any surprises are treated as indicators of inaccurate usage

\section{G. Results, Phase 2}

The Results in phase 2, derived by HDFC bank are discussed in Table 4.

Table: 4 Improved areas in HDFC Corporation after adopting Scrum

\begin{tabular}{|l|l|l|}
\hline $\begin{array}{c}\text { Company/ } \\
\text { Phase }\end{array}$ & $\begin{array}{c}\text { Improved } \\
\text { Areas }\end{array}$ & \multicolumn{1}{|c|}{ Description } \\
\hline HDFC & $\begin{array}{l}\text { Role of } \\
\text { and Scum } \\
\text { Finance } \\
\text { Corporation/ } \\
\text { Phase } 2\end{array}$ & $\begin{array}{l}\text { The management and Scrum } \\
\text { masters have changed the } \\
\text { HDFC organizations and } \\
\text { improvement is being } \\
\text { completed. }\end{array}$ \\
\cline { 2 - 4 } & of adoption & $\begin{array}{l}\text { After one section of the } \\
\text { banking section starts its } \\
\text { adoption of Meta Scrum, the } \\
\text { enterprise may see one more } \\
\text { team moving towards right } \\
\text { path. }\end{array}$ \\
\hline
\end{tabular}

\section{CONCULSION}

In transition Tata Group that develops value added card products and HDFC bank financial services, Meta Scrum with changes in Scrum table provide good results in developing software products both for internal and external customers. It is clear and with good difference it is made sure that projects with Meta Scrum are more successful than actual software development life cycles.

\section{REFERENCES}

1. Liker, J.K.: The Toyota Way: 14 Management Principles from the World's Greatest Manufacturer McGraw-hill New York (2004).P. P Charles \& P. L. Shari, "Security in Computing: $4^{\text {th }}$ edition", Prentice-Hall, Inc.,2008.

2. Poppendieck, M., A History of lean: mFrom Manufacturing to Software Development, in JAOO conference, Aathus, Denmarh, 2005.

3. Reddaiah. B, Pradeep Kumar Reddy. R, Nagaraju. C, Harsha Sree. V, “ A Novel Approach to Adopt Scrum by an Enterprise", Artificial Intelligence and Evolutionary Computations in Engineering Systems, Advances in Intellegent Systems and Computing (2194 - 5365), Vol.394, Springer India 2016, PP.645-654D. KHAN, "The Codebreakers”, Macmillan Publishing Company, New York, 1967.
4. Reddaiah. B, Srinivasa Rao. K "Early Days of Scrum in an Enterprise" International Journal Engineering and Technology (IJET), (0075 4024), Vol.9, No.4, Aug-Sep 2017, PP. 3219-3225.

5. Schwaber K. Agile project management with Scrum. Redmond: Microsoft Press;m2004.

6. Reddaiah. B, Padmaja. M, Vishnupriya. P, Surekha. K, " Handling transition product backlog with Scrum off Scrum," International Journal of Advanced Information Science and Technology (IJAIST), Vol.45, No.45, PP.123-126, 2016.

7. Beck. K, Extreme Programming Explained: Embrace Change, Addison-wesley Longman Pubishing Co., Inc., USA, 1999

8. Schwaber. K, SCRUM development process: Proceedings of the conference on object-oriented programming systems, Languages and applications workshop on business object design and implementation, PP117-134, 1995.

9. Reddaiah. B, Srinivasa Rao. K "Rigidness in Applying Scrum by an Enterprise - Influenced by Muscle Memory" International Journal Engineering and Technology (IJET), (0975 - 4024), Vol.9, No.3, Jun-Jul 2017, PP.2353-2357.

10. Cockbum. A, Highsmith. J, Agile software development: the people factor, IEEE computer 34(11), 2000, PP.131-133.

11. McManus. J, Team agility, Computer Bulletin 45(5), 2003, PP. 70-79.

12. Schatz. B, Abdelshafi., Primavera gets agile: a successful transition to agile development, IEEE software 22(3), 2005, PP.36-42.

13. Schwaber K. Beedle M. Agile software development with Scrum. Prentice Hall; 2002.

\section{AUTHORS PROFILE}

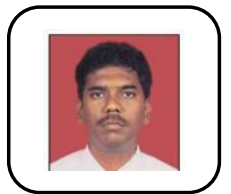

B. Reddaiah, is presently working as Assistant Professor in Department of Computer Applications, Yogi Vemana University, Kadapa, Andhra Pradesh, India. He received his Ph.D Degree in Computer Science and Engineering in 2015 from Acharya Nagarjuna University, Andhra Pradesh. His research areas are Software Engineering and Security. He published 25 papers in various International journal both on Software Engineering and Security.

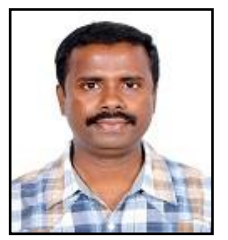

K. Srinivasa, Rao is a Research Scholar in Acharya He received his $\mathrm{M}$. Tech Degree in Computer Science and Engineering from JNTU Hyderabad. At present he is working as Assistant Professor in Yogi Vemana University, Kadapa. He has attended many workshops and published many papers in National and International Journals. 